\title{
Multi-Analytical Approach for Identifying Asbestos Minerals In Situ
}

\author{
Andrea Bloise * (iD and Domenico Miriello \\ Department of Biology, Ecology and Earth Sciences, University of Calabria, \\ Via Pietro Bucci, I-87036 Rende, Italy; miriello@unical.it \\ * Correspondence: andrea.bloise@unical.it; Tel.: +39-0984-493588
}

Received: 19 March 2018; Accepted: 12 April 2018; Published: 15 April 2018

\begin{abstract}
An innovative and, as yet, untested approach is to analyze serpentinite and metabasite rocks containing asbestos using a portable multi-analytical device, which combines portable digital microscopy (p-DM), portable $X$-ray Fluorescence (p-XRF) and portable micro-Raman Spectroscopy $(p-\mu R)$. The analyses were carried out in two inactive quarries of serpentinitic and metabasitic rocks from the Gimigliano-Mount Reventino Unit (Southern Italy) already characterized in previous studies, with the aim of testing the efficiency of these portable tools. In this study, a portable X-ray fluorescence analyzer was used to obtain the in situ rapid chemical discrimination of serpentinite and metabasite rocks. The characterization of outcropping rocks using portable devices enabled us to detect the presence of chrysotile and asbestos tremolite. The results obtained were consistent with the findings from previous research studies and therefore combining $\mathrm{p}-\mathrm{DM}, \mathrm{p}-\mathrm{XRF}$ and $p-\mu R$ could be a useful approach for discriminating asbestos contained in outcropping rocks, especially when sampling is prohibited or for field-based sampling.
\end{abstract}

Keywords: asbestos; chrysotile; asbestos tremolite; portable digital microscope; portable XRF; portable $\mu$-Raman spectroscopy

\section{Introduction}

Harmful asbestos minerals that are regulated by law (in Europe and in several countries worldwide) include chrysotile, tremolite, crocidolite, anthophyllite, actinolite and amosite [1]. Over the last few decades there has been an increase in the incidence of chronic respiratory and degenerative diseases caused by exposure to airborne asbestos from artificial and natural sources [2,3]. Due to their outstanding characteristics, asbestos fibers were used in more than 3000 industrial applications and for manufacturing various types of products (e.g., asbestos cement, eternit, disc brake pads) known as asbestos-containing materials (ACMs) from 1720 until the 1980s [4]. The associated occupational health hazards have been investigated and identified [5-8]. In Europe and several other countries, the asbestos prohibition laws [9] banning the use of asbestos fibers have reduced the number of workers currently exposed to asbestos. However, asbestos fibers can be hosted in serpentinite or metabasite rocks whose outcrops are known as naturally occurring asbestos (NOA) [10-15]. Until the enactment of laws $[9,16]$, which regulates the extraction, processing and use of rocks containing asbestos fibers, these rocks were quarried and used indiscriminately for various purposes. For example, ever since antiquity serpentinite and metabasite have been used as building materials and ornamental stones worldwide $[17,18]$.

In recent years several studies have focused on NOA with the aim of determining the potential health risks for neighboring populations [19-23]. This is due to the relatively widespread presence of NOA that are currently being excavated for numerous construction projects (railway lines, motorways etc.). Environmental NOA exposure is known to cause several types of lung disease [24,25]. 
Human health can be damaged by inhaling fibers when they become airborne due to weathering or human activities that produce dust [22,26]. Moreover, it is important to note that asbestos minerals may host many toxic elements (e.g., $\mathrm{Cr}, \mathrm{Ni}$ ) [27,28], indeed serpentinite and metabasite derived soils are usually rich in heavy metals, which are known to have a negative impact on environmental quality and on agricultural activity [26,29].

Nowadays, due to the adverse health effects associated with asbestos exposure, various laboratory techniques are used to characterize the occurrence of asbestos fibers in rock samples [30-36]. Although to date sporadic studies have been carried out on asbestos identification using portable devices [37,38], in recent years both the portable XRF and portable Raman techniques have been successfully used for the chemical and mineralogical characterization of rocks and artifacts [39,40].

The aim of our study is to promote the portable monitoring of asbestos fibers present in rock outcrops, using portable digital microscope (p-DM), portable X-ray fluorescence (p-XRF) and portable $\mu$-Raman spectroscopy $(\mathrm{p}-\mu \mathrm{R})$. To achieve this ambitious goal, we cross-checked the data obtained from the $\mathrm{p}-\mathrm{DM}, \mathrm{p}-\mathrm{XRF}$ and $\mathrm{p}-\mu \mathrm{R}$ on the serpentinites and metabasites outcropping in the Gimigliano-Mount Reventino Unit (GMRU) [14,41]. Previous studies [15,42,43] identified chrysotile and tremolite as the two asbestiform minerals detected in the serpentinites and metabasites inactive quarries outcropping in the GMRU. Chrysotile $\mathrm{Mg}_{3} \mathrm{Si}_{2} \mathrm{O}_{5}(\mathrm{OH})_{4}$, is one of the three main forms of serpentine while tremolite $\mathrm{Ca}_{2} \mathrm{Mg}_{5} \mathrm{Si}_{8} \mathrm{O}_{22}(\mathrm{OH})_{2}$ belongs to a calcic amphibole group [28]. The toxicology of chrysotile, such as tremolite asbestos, is associated with size, durability, and chemical composition $[27,44,45]$.

In this study, we present the possible applications of $\mathrm{p}-\mathrm{DM}, \mathrm{p}-\mathrm{XRF}$ and $\mathrm{p}-\mu \mathrm{R}$ to determine their efficiency in identifying asbestos minerals under field conditions. This fact was never recognized in previous papers. Portable techniques that can identify asbestos minerals in situ in polluted areas (NOA-inactive quarries) or on asbestos-containing materials (ACMs), could provide support to conventional analytical techniques to facilitate and accelerate qualitative field analysis of asbestos minerals.

\section{Geological Setting}

The study area occurs on Mount Reventino (Figure 1) located in the Sila Piccola in the northern sector of the Calabrian-Peloritan Orogen [41,46]. This is a nappe pile, which can be described as the superposition of three major structural elements that represent different paleogeographic domains: (i) The Apennine Units Complex made up of Mesozoic sedimentary and metasedimentary successions (Trias-Miocene) [47]; (ii) The structurally intermediate allochthonous Alpine Liguride nappe (Tithonian-Neocomian) made up of a series of Alpine metamorphic units including a Cretaceous-Paleogene metapelitic-ophiolitic-carbonate assemblage [41,46]; (iii) The Calabride Complex formed by Hercynian and pre-Hercynian gneiss, granite and metapelite. The Liguride nappe consists of HP-LT ophiolitic sequences, in which a metabasic and metaultramafic association constitutes the basis of a complex metasedimentary cover, ranging from pelagic to flyschoid types of sediments [41]. The ophiolitic sequence includes: (i) a serpentinized mantle of ultramafic rocks and ophicalcites, cropping out only in the Gimigliano-Mount Reventino area and in close association with overlying metabasites; (ii) metabasalts and subordinate metadolerites, with transitional MORB affinity; (iii) a metasedimentary cover including both flyschoid facies and pelagic facies, composed of alternating metapelites, metalimestones and metarenites of uncertain ages. The geology of Mount Reventino is characterized mainly by lenses of metabasalts and serpentinites limited in contact, by low angle tectonic systems [41] with the metarenites and metapelites of the Frido Unit [48]. The massive-banded metabasalts and serpentinites lenses constitute the summit of Mount Reventino. In the ophiolitic bodies, the serpentinites occupy the cores of the major tight folds and are partially or completely surrounded by isolated bodies of metabasalts [41,49]. 


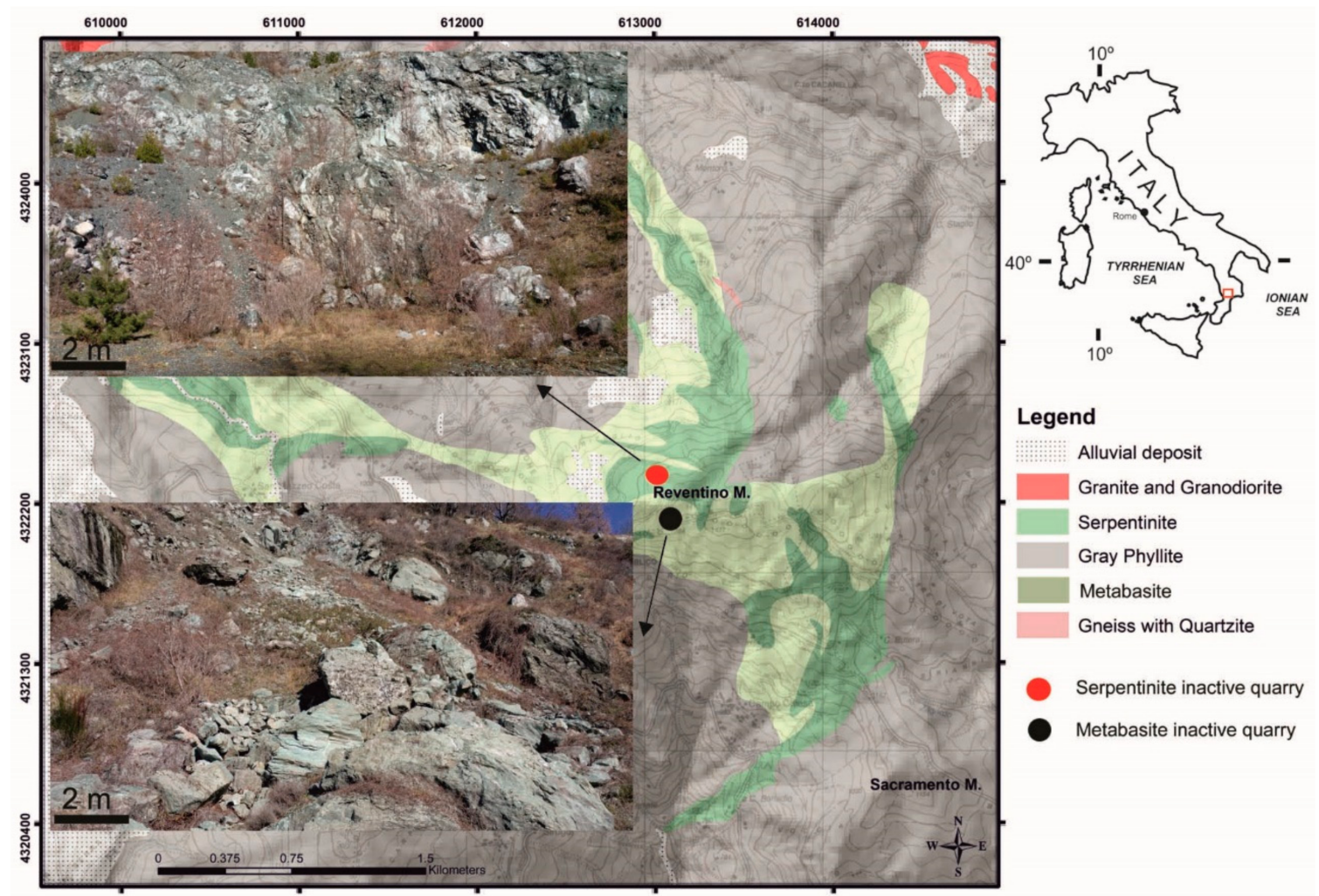

Figure 1. Simplified geological map of the investigated area with the location of measurement sites (after, [15]), in the upper left corner distant view of the serpentine inactive quarry; bottom left distant view of metabasite inactive quarry. The geographic position of the quarries are indicated by Universal Transverse Mercator (UTM) projection.

\section{Materials and Methods}

Measuring points were acquired in two inactive quarries located in Mount Reventino (Figure 1). The crystallinity, chemistry, thermal behavior, and other characteristics of minerals found in inactive serpentinite and metabasite quarries have already been reported $[15,42,43]$. Collected $p-\mu R$ spectra as p-XRF spectra, were conducted exclusively on fibrous morphologies found inside the serpentinite and metabasite veins, observed using p-DM and Raman microscope. In the field, the analyzed points were preliminarily inspected with reflected light using a Colemeter USB Handheld (ColeMeter Instruments Co. Ltd: HongKong, China) $(500 \times)$ p-DM to select a more fibrous area to analyze with $\mathrm{p}-\mathrm{XRF}$ and $\mathrm{p}-\mu \mathrm{R}$.

P-XRF was performed using a spectrometer "Bruker Tracer IV-SD"(Bruker Corporation: Billerica, Massachusetts, MA, USA) equipped with a Rh X-ray tube; the following conditions were used for the analyses: acceleration voltage of $40 \mathrm{kV}$, current intensity of $35 \mu \mathrm{A}$, spectrum accumulation of $120 \mathrm{~s}$, vacuum $<17$ Torr, no filters, spot size of approximately $5 \mathrm{~mm}$. The element assignments were defined with "Bruker AXS MA Artax 7.4" software. The peak intensities for the p-XRF spectra were indicated as counts per second (cps).

P- $\mu$ R were performed by a I-Raman B\&WTEK, model BWS415 Spectrometer (B\&W Tek: Newark, New Jersey, USA), coupled with A BAC151B portable microscope (B\&W Tek: Newark, New Jersey, USA), using 40 and $80 \times$ magnification. The 532.0-nm line was used at an incident power output of 7.4 to $\mathrm{mW}$.

\section{Results and Discussion}

Firstly, the two inactive quarries were visually inspected (Figure 2a) to identify the points on which to perform the analyses. Before carrying out the $\mathrm{p}-\mathrm{XRF}$ and $\mathrm{p}-\mu \mathrm{R}$ analyses, a morphological 
investigation was carried out on the veins of the serpentinite (Figure 3a) and metabasite rocks (Figure $3 b$ ) using a p-DM to determine the occurrence of fibrous minerals.


Figure 2. (a) Preliminary site survey, (b) p-XRF data collection, (c) closely view data collection by $\mathrm{p}-\mathrm{XRF},(\mathrm{d}) \mathrm{p}-\mu \mathrm{R}$ data collection. Veins indicated by red arrow.


Figure 3. (a) Veins network developing inside massive serpentinite, note the arrangement of elastic fibers inside the veins, (b) asbestos tremolite in outcrop at the mesoscale, note as tremolite appear straight, poorly flexible and exhibit a needle-like crystal habit. Veins indicated by arrow and dotted red lines.

At the scale of the outcrop, the dark green serpentinites look massive with veins network and lamellar morphology developing inside; the fibers were either isolated or wrapped in flexible bundles (Figure 3a). Straight, white fibers were found inside the metabasite rocks (Figure 3b). The p-XRF (Figure $2 b, c$ ) and $p-\mu R$ analyses (Figure $2 d$ ) were carried out on the same points inside the veins where fibrous morphologies were observed (Figure 3). Only inside the veins was possible to identify fibers by $\mathrm{p}-\mathrm{DM}$ while no fibrous chrysotile and tremolite was detected from rock mass surrounding the veins. 
Thickness of veins which cross-cut the massive serpentinites and metabasite bodies, ranges from a few millimeters to $1-3 \mathrm{~cm}$ (Figure $2 \mathrm{~b}, \mathrm{c}$, and Figure 3).

Figure 4 shows the fluorescence spectra of the serpentinite and metabasite rocks. As expected, the spectra are very different, serpentinite shows the presence of $\mathrm{Si}, \mathrm{Fe}, \mathrm{Ni}, \mathrm{Mg}$, $\mathrm{Mn}$ with minor $\mathrm{Al}, \mathrm{Ti}$ and $\mathrm{Cr}$ while metabasite XRF spectra showed substantially the same elements but with the addition of calcium (Figure 4). The presence of $\mathrm{Rh}$ is not attributable to the matrix analyzed, but it comes from the source emission.

The presence of these chemical elements, enabled us to put forward some hypotheses on the minerals hosted in serpentinite and metabasite rocks. The presence of $\mathrm{Si}$, $\mathrm{Fe}$ and $\mathrm{Mg}$ indicate the presence of serpentine minerals (chrysotile, lizardite and antigorite) in the serpentinitic rocks. However, the mineralogical composition of serpentinites is rather complex.

The discrimination of the all serpentine varieties [50] using only p-XRF was not possible due to the negligible chemical differences between serpentine phases; in fact, chrysotile, antigorite and lizardite have a very similar chemical composition [28], usually close to the magnesian end-member $\mathrm{Mg}_{3} \mathrm{Si}_{2} \mathrm{O}_{5}(\mathrm{OH})_{4}$.

Under these conditions, the data are not quantitative; however, in the first step the presence of Fe, $\mathrm{Ni}$ and $\mathrm{Mn}$ in serpentinite could suggest both an isomorphous substitution of $\mathrm{Mg}$ in the octahedral sites of serpentine minerals $[51,52]$ and/or the presence of mineral impurities combined with serpentine minerals (e.g., chlorite, magnetite). Other elements are also detected in serpentine minerals such as $\mathrm{Ti}$, $\mathrm{Cr}$, (Figure 4), which represent an almost exclusively isomorphous substitution of $\mathrm{Mg}$ [53].

The presence of $\mathrm{Ca}$ in metabasite rocks as well as $\mathrm{Si}, \mathrm{Fe}$ and $\mathrm{Mg}$ suggests the presence of tremolite or actinolite. In the first step, the presence of $\mathrm{Cr}$, Fe and $\mathrm{Ni}$ (Figure 4) are confirmed by data reported in literature [42,54]. In fact, Fe could be a suitable substitute for Mg in the M(1), M(2), M(3), M(4) sites of tremolite $[28,55]$.

Moreover, these results are in line with a previous study which reported that Ni can occupy the specific crystallographic $\mathrm{M}(1)$ and $\mathrm{M}(3)$ sites in calcic amphibole [56] and $\mathrm{Cr}$ can be a major component in calcic amphiboles occupying mainly $\mathrm{M}(2)$ sites [55]. These p-XRF data could be used to make a sampling plan aimed at identifying hotspot areas of heavy metal contamination such as the asbestos quarries/mines in Italy, Canada, India, and Argentina [20,41,57-59].

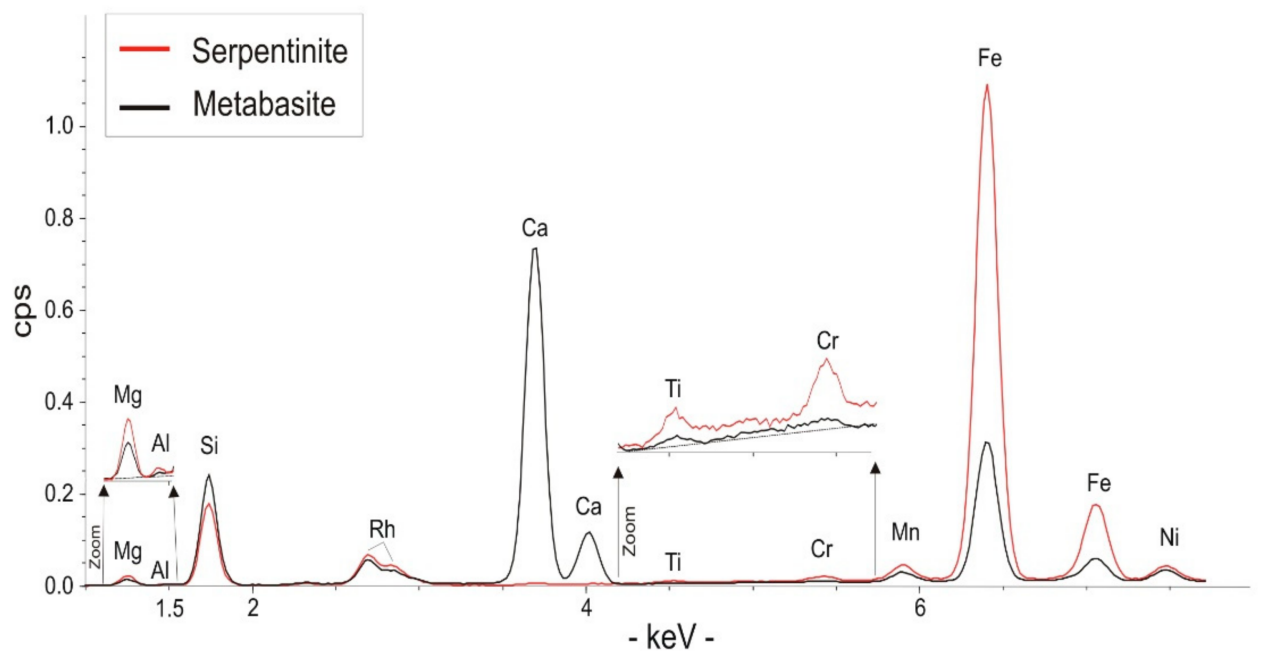

Figure 4. p-XRF spectra of serpentinitic and metabasitic rocks.

Collected Raman spectra as p-XRF spectra, were conducted exclusively on fibrous morphologies observed inside the serpentinite veins (Figure 3a) using Raman microscope and p-DM. The authors are aware that the identification of the fibrous morphology of minerals is not proof of the presence of asbestos minerals. In fact, both chrysotile and amphibole fibers hosted in serpentinite and metabasite 
rocks may exhibit intergrowth with other fibrous minerals at a submicrometric scale which are not classified as asbestos minerals (e.g., polygonal serpentine, fibrous diopside, fibrous antigorite and fibrous talc) [60] as well as fibrous erionite [61]. Therefore, characterization using $p-\mu R$ was essential to confirm the previous hypotheses based on the chemical composition and morphological observations.

The study of the serpentinite using $\mathrm{p}-\mu \mathrm{R}$ confirmed the presence of serpentine minerals (Figure 5). Indeed, the Raman spectra show the patterns reported in Figure 5a, which unambiguously identify chrysotile [62,63]. In fact, it is possible to observe the bands of the chrysotile at 694, 387 and $232 \mathrm{~cm}^{-1}$ (Figure 5a). Moreover, antigorite of lamellar morphology was detected in the veins of serpentinitic rocks. In particular, Raman spectrum shows (Figure $5 b$ ) the characteristic bands at 683 , 377 and $230 \mathrm{~cm}^{-1}[62,63]$.
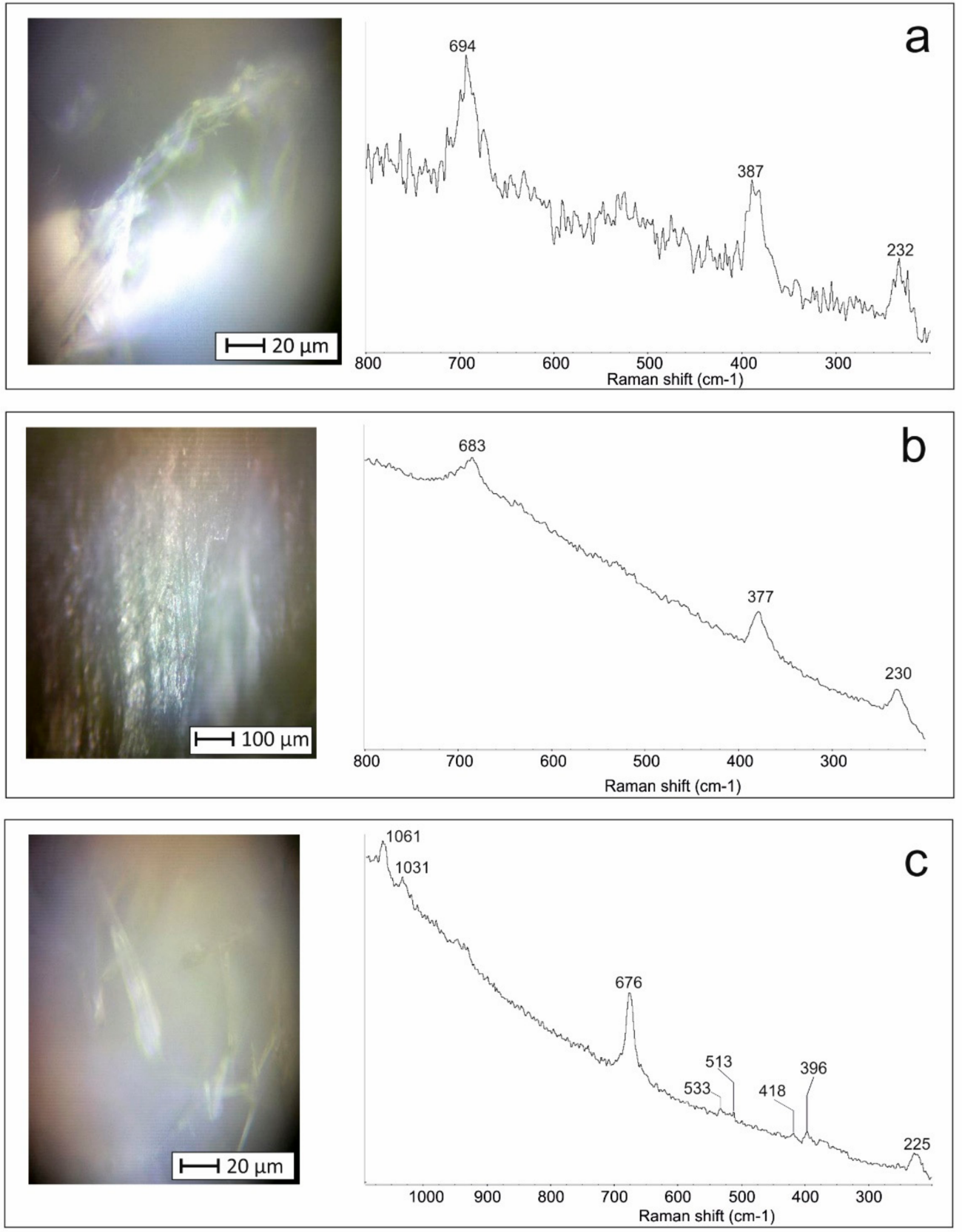

Figure 5. (a) $p-\mu R$ spectrum identifying chrysotile fibers, (b) $p-\mu R$ spectrum identifying lamellar antigorite, (c) $\mathrm{p}-\mu \mathrm{R}$ spectrum identifying fibrous tremolite. 
Other serpentine minerals such as lizardite and polygonal serpentine were not found, which is consistent with previous findings [15,42,43]. Figure $5 \mathrm{c}$ shows the points analyzed on metabasite using $\mathrm{p}-\mu \mathrm{R}$ which revealed the presence of amphiboles. In particular, Raman spectra shows the typical tremolite bands at 1061, 1031, 676, 533, 513, 418, 396 and $225 \mathrm{~cm}^{-1}$ [64-66]. These Raman bands agreed with the findings of Jehlička et al. [37] by portable Raman, however it is important to note that the morphology (i.e., fibrous or tabular) of the tremolite investigated by Jehlička et al. [37] was not specified therefore it is unworkable to make comparisons with our fibrous tremolite.

This study outlined that in both serpentinite and metabasite rocks, there are asbestos minerals such as chrysotile and asbestos tremolite, suggesting that human activities can disturb and provoke the release of inhalable asbestos in the atmosphere, triggering thus mechanisms of hazardous exposition for population. Since the dispersion of fibers could be associated with carcinogenic lung cancer, in our opinion in areas where NOA can be found, the institutions should publish local maps indicating areas with mineralogical concern and realization of constructions (e.g., civil constructions, building stones, road yards and quarry excavations) must have dust control measure to avoid hazardous exposures.

\section{Conclusions}

In the serpentinitic and metabasite rocks outcropping in the inactive quarries in the Gimigliano-Mount Reventino Unit (S-Italy), asbestos fibrous minerals such as chrysotile and asbestos tremolite, for the first time were identified by cross-checking the data obtained from p-DM, p-XRF and $\mathrm{p}-\mu \mathrm{R}$.

The portable digital microscope enables us to distinguish fibrous and other morphologies. Analysis with p-XRF is not sufficient to solve the issues regarding the identification of asbestos minerals, however it enables us to distinguish between serpentinitic and amphibole asbestos phases. Finally, the chrysotile and tremolite asbestos were easily identified due to their characteristic Raman spectrum. The asbestos minerals found in the outcrops analyzed are consistent with the findings of previous studies $[15,42,43]$. This study highlights the versatility and effectiveness of portable micro-Raman Spectroscopy which enables us to obtain reliable information on the mineralogical distinction between different fibrous phases (i.e., chrysotile and tremolite).

The authors are aware that conventional laboratory analyses must be carried out to obtain an accurate mineralogical characterization of outcropping minerals. However, the simultaneous use of portable analyzers ( $\mathrm{p}-\mathrm{DM}, \mathrm{p}-\mathrm{XRF}$ and $\mathrm{p}-\mu \mathrm{R}$ ) may prove useful for: (i) the rapid identification of fibrous asbestos minerals especially when sampling is not possible (e.g., doorways of churches or columns with serpentinite rocks); (ii) developing a targeted sampling plan for identifying areas polluted with both asbestos minerals and heavy metals. Moreover, this approach can be preparatory for optimizing additional specific techniques aimed at classifying NOA.

Acknowledgments: The authors thank Mirco Taranto for the support during data collection. The work has received financial support from University of Calabria.

Author Contributions: Andrea Bloise and Domenico Miriello conceived the research and performed p-DM, $\mathrm{p}-\mathrm{XRF}$ and $\mathrm{p}-\mu \mathrm{R}$ measurements, analyzed the results and wrote the manuscript.

Conflicts of Interest: The authors declare no conflict of interest.

\section{References}

1. WHO. Asbestos and other Natural Mineral Fibres, Environmental Health Criteria, 53; World Health Organization: Geneva, Switzerland, 1986; 194p.

2. Pan, X.L.; Day, H.W.; Wang, W.; Beckett, L.A.; Schenker, M.B. Residential proximity to naturally occurring asbestos and mesothelioma risk in California. Am. J. Respir. Crit. Care Med. 2005, 172, 1019-1025. [CrossRef] [PubMed]

3. Baumann, F.; Buck, B.J.; Metcalf, R.V.; McLaurin, B.T.; Merkler, D.J.; Carbone, M. The presence of asbestos in the natural environment is likely related to mesothelioma in young individuals and women from Southern Nevada. J. Thorac. Oncol. 2015, 10, 731-737. [CrossRef] [PubMed] 
4. Gualtieri, A.F. Mineral fibre-based building materials and their health hazards. In Toxicity of Building Materials; Pacheco-Torgal, F., Jalali, S., Fucic, A., Eds.; Woodhead Publishing: Cambridge, UK, 2012; pp. 166-195.

5. Niklinski, J.; Niklinska, W.; Chyczewska, E.; Laudanski, J.; Naumnik, W.; Chyczewski, L.; Pluygers, E. The epidemiology of asbestos-related diseases. Lung Cancer 2004, 45, S7-S15. [CrossRef] [PubMed]

6. Doll, R. Mortality from lung cancer in asbestos workers. Br. J. Ind. Med. 1955, 12, 81-86. [CrossRef] [PubMed]

7. Rohl, A.N.; Langer, A.M.; Selikoff, I.J. Environmental asbestos pollution related to use of quarried serpentine rock. Science 1977, 196, 1319-1322. [CrossRef] [PubMed]

8. Emmanouil, K.; Kalliopi, A.; Dimitrios, K.; Evangelos, G. Asbestos pollution in an inactive mine: Determination of asbestos fibers in the deposit tailings and water. J. Hazard Mater. 2009, 167, 1080-1088.

9. Cox, P.; Efthymiou, P. Directive 2003/18/EC of the European Parliament and of the Council of 27th March 2003 amending Council Directive 83/477/EEC on the protection of workers from the risks related to exposure to asbestos at work. Off. J. Eur. Union 2003, 97, 48-52.

10. Van Gosen, B.S. The geology of asbestos in the United States and its practical applications. Environ. Eng. Geosci. 2007, 13, 55-68. [CrossRef]

11. Karkanas, P. The slip-fiber chrysotile asbestos deposit in the Zidani area, northern Greece. Ore Geol. Rev. 1995, 10, 19-29. [CrossRef]

12. Giacomini, F.; Boerio, V.; Polattini, S.; Tiepolo, M.; Tribuzio, R.; Zanetti, A. Evaluating asbestos fibre concentration in metaophiolites: A case study from the Voltri Massif and Sestri-Voltaggio Zone (Liguria, NW Italy). Environ. Earth Sci. 2010, 61, 1621-1639. [CrossRef]

13. Vignaroli, G.; Rossetti, F.; Belardi, G.; Billi, A. Linking rock fabric to fibrous mineralisation: A basic tool for the asbestos hazard. Nat. Hazards Earth Syst. Sci. 2011, 11, 1267-1280. [CrossRef]

14. Bloise, A.; Belluso, E.; Critelli, T.; Catalano, M.; Apollaro, C.; Miriello, D.; Barrese, E. Amphibole asbestos and other fibrous minerals in the meta-basalt of the gimigliano-mount reventino unit (Calabria, South-Italy). Rend. Online Soc. Geol. It. 2012, 21, 847-848.

15. Bloise, A.; Critelli, T.; Catalano, M.; Apollaro, C.; Miriello, D.; Croce, A.; Barrese, E.; Liberi, F.; Piluso, E.; Rinaudo, C.; et al. Asbestos and other fibrous minerals contained in the serpentinites of the Gimigliano-Mount Reventino unit (Calabria, S-Italy). Environ. Earth. Sci. 2014, 71, 3773-3786. [CrossRef]

16. Decreto ministeriale 14 maggio 1996: Normative e metodologie tecniche per gli interventi di bonifica, ivi compresi quelli per rendere innocuo l'amianto, previsti dall'art; Ministero della Sanità: Lungotevere Ripa, Roma, Italy, 1996.

17. Pereira, D. A report on serpentinites in the context of heritage stone resources. Episodes 2012, 35, 478-480.

18. Guillot, S.; Hattori, K. Serpentinites: Essential roles in geodynamics, arc volcanism, sustainable development, and the origin of life. Elements 2013, 9, 95-98. [CrossRef]

19. Dichicco, M.C.; Laurita, S.; Sinisi, R.; Battiloro, R.; Rizzo, G. Environmental and Health: The Importance of Tremolite Occurence in the Pollino Geopark (Southern Italy). Geosciences 2018, 8, 98. [CrossRef]

20. Gualtieri, A.F.; Pollastri, S.; Gandolfi, N.B.; Ronchetti, F.; Albonico, C.; Cavallo, A.; Zanetti, G.; Marini, P.; Sala, O. Determination of the concentration of asbestos minerals in highly contaminated mine tailings: An example from inactive mine waste of Cre'taz and E'marese (Valle d'Aosta, Italy). Am. Miner. 2014, 99, 1233-1247. [CrossRef]

21. Vignaroli, G.; Ballirano, P.; Belardi, G.; Rossetti, F. Asbestos fibre identification vs. evaluation of asbestos hazard in ophiolitic rock mélanges, a case study from the Ligurian Alps (Italy). Environ. Earth Sci. 2014, 72, 3679-3698. [CrossRef]

22. Bloise, A.; Catalano, M.; Critelli, T.; Apollaro, C.; Miriello, D. Naturally occurring asbestos: Potential for human exposure, San Severino Lucano (Basilicata, Southern Italy). Environ. Earth Sci. 2017, 76, 648. [CrossRef]

23. Gaggero, L.; Sanguineti, E.; Yus González, A.; Militello, G.M.; Scuderi, A.; Parisi, G. Airborne asbestos fibres monitoring in tunnel excavation. J. Environ. Manag. 2017, 196, 583-593. [CrossRef] [PubMed]

24. Harper, M. 10th Anniversary critical review: Naturally occurring asbestos. J. Environ. Monit. 2008, 10, 1394-1408. [CrossRef] [PubMed]

25. Culley, M.R.; Zorland, J.; Freire, K. Community responses to naturally occurring asbestos: Implications for public health practice. Health Educ. Res. 2010, 25, 877-891. [CrossRef] [PubMed]

26. Bloise, A.; Punturo, R.; Catalano, M.; Miriello, D.; Cirrincione, R. Naturally occurring asbestos (NOA) in rock and soil and relation with human activities: The monitoring example of selected sites in Calabria (southern Italy). Ital. J. Geosci. 2016, 135, 268-279. [CrossRef] 
27. Bloise, A.; Barca, D.; Gualtieri, A.F.; Pollastri, S.; Belluso, E. Trace elements in hazardous mineral fibres. Environ. Pollut. 2016, 216, 314-323. [CrossRef] [PubMed]

28. Ballirano, P.; Bloise, A.; Gualtieri, A.F.; Lezzerini, M.; Pacella, A.; Perchiazzi, N.; Dogan, M.; Dogan, A.U. The crystal structure of mineral fibres. In Mineral Fibres: Crystal Chemistry, Chemical-Physical Properties, Biological Interaction and Toxicity; Gualtieri, A.F., Ed.; European Mineralogical Union: London, UK, 2017; Volume 18, pp. 17-53.

29. Moore, T.R.; Zimmermann, R.C. Establishment of vegetation on serpentine asbestos mine wastes, southeastern Quebec, Canada. J. Appl. Ecol. 1977, 14, 589-599. [CrossRef]

30. Groppo, C.; Rinaudo, C.; Cairo, S.; Gastaldi, D.; Compagnoni, R. Micro-Raman spectroscopy for a quick and reliable identification of serpentine minerals from ultramafics. Eur. J. Mineral. 2006, 18, 319-329. [CrossRef]

31. Harris, K.E.; Bunker, K.L.; Strohmeier, B.R.; Hoch, R.; Lee, R.J. Discovering the True Morphology of Amphibole Minerals: Complementary TEM and FESEM Characterization of Particles in Mixed Mineral Dust; Meddez-Vilas, A., Diaz, J., Eds.; Formatex Research Center: Badajoz, Spain, 2007; pp. 643-658.

32. Viti, C. Serpentine minerals discrimination by thermal analysis. Am. Miner. 2010, 95, 631-638. [CrossRef]

33. Vigliaturo, R.; Capella, S.; Rinaudo, C.; Belluso, E. "Rinse and trickle": A protocol for TEM preparation and investigation of inorganic fibers from biological material. Inhal. Toxicol. 2016, 28, 357-363. [CrossRef] [PubMed]

34. Pollastri, S.; Gualtieri, A.F.; Gualtieri Lassinantti, M.; Hanuskova, M.; Cavallo, A.; Gaudino, G. The zeta potential of mineral fibres. J. Hazard. Mater. 2014, 276, 469-479. [CrossRef] [PubMed]

35. Campopiano, A.; Olori, A.; Cannizzaro, A.; Iannò, A.; Capone, P.P. Quantification of tremolite in friable material coming from Calabrian ophiolitic deposits by infrared spectroscopy. J. Spectrosc. 2015, 2015, 1-9. [CrossRef]

36. Bonifazi, G.; Capobianco, G.; Serranti, S. Asbestos containing materials detection and classification by the use of hyperspectral imaging. J. Hazard. Mater. 2018, 344, 981-993. [CrossRef] [PubMed]

37. Jehlička, J.; Vítek, P.; Edwards, H.G.M.; Heagraves, M.; Čapoun, T. Application of portable Raman instruments for fast and non-destructive detection of minerals on outcrops. Spectrochim. Acta Mol. Biomol. Spectrosc. 2009, 73, 410-419. [CrossRef] [PubMed]

38. Petriglieri, J.R.; Laporte-Magoni, C.; Salvioli-Mariani, E.; Gunkel-Grillon, P.; Tribaudino, M.; Mantovani, L.; Bersani, D.; Lottici, P.P.; Tomatis, M. Monitoring environmental risk in fibrous minerals in New Caledonia: A comparison between different analytical methods. Proceedings of EGU General Assembly Conference, Vienna, Austria, 23-28 April 2017; p. 14544.

39. Tykot, R.H. Using Nondestructive Portable X-ray Fluorescence Spectrometers on Stone, Ceramics, Metals, and Other Materials in Museums: Advantages and Limitations. Appl. Spectrosc. 2016, 70, 42-56. [CrossRef] [PubMed]

40. Miriello, D.; Bloise, A.; Crisci, G.M.; De Luca, R.; De Nigris, B.; Martellone, A.; Osanna, M.; Pace, R.; Pecci, A.; Ruggeri, N. Non-destructive multi-analytical approach to study the pigments of wall painting fragments reused in mortars from the archaeological site of Pompeii (Italy). Minerals 2018, 8, 134. [CrossRef]

41. Cirrincione, R.; Fazio, E.; Fiannacca, P.; Ortolano, G.; Pezzino, A.; Punturo, R. The Calabria-Peloritani Orogen, a composite terrane in Central Mediterranean; its overall architecture and geodynamic significance for a pre-Alpine scenario around the Tethyan basin. Period. Mineral. 2015, 84, 701-749.

42. Apollaro, C.; Fuoco, I.; Vespasiano, G.; De Rosa, R.; Cofone, F.; Miriello, D.; Bloise, A. Geochemical and mineralogical characterization of tremolite asbestos contained in the Gimigliano-Monte Reventino Unit (Calabria, south Italy). J. Mediterr. Earth Sci. 2008, in press.

43. Punturo, R.; Bloise, A.; Critelli, T.; Catalano, M.; Fazio, E.; Apollaro, C. Environmental implications related to natural asbestos occurrences in the ophiolites of the Gimigliano-Mount Reventino Unit (Calabria, Southern Italy). Int. J. Environ. Res. 2015, 9, 405-418.

44. Mossman, B.T.; Lippmann, M.; Hesterberg, T.W.; Kelsey, K.T.; Barchowsky, A.; Bonner, J.C. Pulmonary endpoints (lung carcinomas and asbestosis) following inhalation exposure to asbestos. J. Toxicol. Environ. Health 2011, 14, 76-121. [CrossRef] [PubMed]

45. Pugnaloni, A.; Giantomassi, F.; Lucarini, G.; Capella, S.; Bloise, A.; Di Primio, R.; Belluso, E. Cytotoxicity induced by exposure to natural and synthetic tremolite asbestos: An in vitro pilot study. Acta Histochem. 2013, 115, 100-112. [CrossRef] [PubMed] 
46. Liberi, F.; Piluso, E. Tectonometamorphic evolution of the ophiolitic sequences from Northern Calabrian Arc. Ital. J. Geosci. 2009, 128, 483-493.

47. Iannace, A.; Vitale, S.; D’Errico, M.; Mazzoli, S.; Di Staso, A.; Macaione, E.; Messina, A.; Reddy, S.M.; Somma, R.; Zamparelli, V.; et al. The carbonate tectonic units of northern Calabria (Italy): A record of Apulian palaeomargin evolution and Miocene convergence, continental crust subduction, and exhumation of HP-LT rocks. J. Geol. Soc. 2007, 164, 1165-1186. [CrossRef]

48. Vitale, S.; Fedele, L.; Tramparulo, F.; Ciarcia, S.; Mazzoli, S.; Novellino, A. Structural and petrological analyses of the Frido Unit (southern Italy): New insights into the early tectonic evolution of the southern Apennines-Calabrian Arc system. Lithos 2013, 168, 219-235. [CrossRef]

49. Alvarez, W. Structure of the Monte Reventino greenschist folds: A contribution to untangling the tectonic-transport history of Calabria, a key element in Italian tectonics. J. Struct. Geol. 2005, 27, 1355-1378. [CrossRef]

50. Andreani, M.; Grauby, O.; Baronnet, A.; Munoz, M. Occurrence, composition and growth of polyhedral serpentine. Eur. J. Mineral. 2008, 20, 159-171. [CrossRef]

51. Bloise, A.; Belluso, E.; Barrese, E.; Miriello, D.; Apollaro, C. Synthesis of Fe-doped chrysotile and characterization of the resulting chrysotile fibers. Cryst. Res. Technol. 2009, 44, 590-596. [CrossRef]

52. Bloise, A.; Belluso, E.; Fornero, E.; Rinaudo, C.; Barrese, E.; Capella, S. Influence of synthesis conditions on growth of Ni-doped chrysotile. Microporous Mesoporous Mater. 2010, 132, 239-245. [CrossRef]

53. Bloise, A.; Kusiorowski, R.; Lassinantti Gualtieri, M.; Gualtieri, A.F. Thermal behaviour of mineral fibres. In Mineral Fibres: Crystal Chemistry, Chemical-Physical Properties, Biological Interaction and Toxicity; Gualtieri, A.F., Ed.; European Mineralogical Union: London, UK, 2017; Volume 18, pp. 215-252.

54. Apollaro, C.; Marini, L.; Critelli, T.; Barca, D.; Bloise, A.; De Rosa, R.; Liberi, F.; Miriello, D. Investigation of rock-to-water release and fate of major, minor, and trace elements in the metabasalteserpentinite shallow aquifer of Mt. Reventino (CZ, Italy) by reaction path modelling. Appl. Geochem. 2011, 26, 1722-1740. [CrossRef]

55. Oberti, R.; Hawthorne, F.C.; Cannillo, E.; Camara, F. Long-range order in amphiboles. In Reviews in Mineralogy and Geochemistry; Hawthorne, F.C., Oberti, R., Della Ventura, G., Mottana, A., Eds.; Mineralogical society of America geochemical society: Chantilly, France, 2007; Volume 67, pp. 125-172.

56. Della Ventura, G.; Robert, J.-L.; Raudsepp, M.; Hawthorne, F.C.; Welch, M.D. Site occupancies in synthetic monoclinic amphiboles: Rietveld structure refinement and infrared spectroscopy of (nickel, magnesium, cobalt)-richterite. Am. Miner. 1997, 82, 291-301. [CrossRef]

57. Kumar, A.; Maiti, S.K. Assessment of potentially toxic heavy metal contamination in agricultural fields, sediment, and water from an abandoned chromite-asbestos mine waste of Roro hill, Chaibasa, India. Environ. Earth Sci. 2015, 74, 2617-2633. [CrossRef]

58. Lescano, L.; Locati, F.; Sfragulla, J.; Marfil, S.; Bonalumi, A.; Maiza, P. Asbestiform and non-asbestiform morphologies in a talc and vermiculite mine from the province of Córdoba (Argentina): A case study. Environ. Earth Sci. 2017, 76, 631. [CrossRef]

59. Cavallo, A.; Rimoldi, B. Chrysotile asbestos in serpentinite quarries: A case study in Valmalenco, Central Alps, Northern Italy. Environ. Sci. Process. Impacts 2013, 15, 1341-1350. [CrossRef] [PubMed]

60. Gunter, M.E.; Belluso, E.; Mottana, A. Amphiboles: Environmental and health concerns. In Reviews in Mineralogy and Geochemistry; Hawthorne, F.C., Oberti, R., Della Ventura, G., Mottana, A., Eds.; Mineralogical society of America geochemical society: Chantilly, France, 2007; Volume 67, pp. 453-516.

61. Ballirano, P.; Pacella, A.; Bloise, A.; Giordani, M.; Mattioli, M. Thermal Stability of Woolly Erionite-K and Considerations about the Heat-Induced Behaviour of the Erionite Group. Minerals 2018, 8, 28. [CrossRef]

62. Rinaudo, C.; Gastaldi, D.; Belluso, E. Characterization of chrysotile, antigorite and lizardite by FT-Raman spectroscopy. Can. Mineral. 2003, 41, 883-890. [CrossRef]

63. Petriglieri, J.R.; Salvioli-Mariani, E.; Mantovani, L.; Tribaudino, M.; Lottici, P.P.; Laporte-Magoni, C.; Bersani, D. Micro-Raman mapping of the polymorphs of serpentine. J. Raman Spectrosc. 2015, 46, 953-958. [CrossRef]

64. Rinaudo, C.; Belluso, E.; Gastaldi, D. Assessment of the use of Raman spectroscopy for the determination of amphibole asbestos. Mineral. Mag. 2004, 68, 455-465. [CrossRef] 
65. Bloise, A.; Fornero, E.; Belluso, E.; Barrese, E.; Rinaudo, C. Synthesis and characterization of tremolite asbestos fibres. Eur. J. Mineral. 2008, 20, 1027-1033. [CrossRef]

66. Della Ventura, G. The analysis of asbestos minerals using vibrational spectroscopies (FTIR, Raman): Crystal-chemistry, identification and environmental applications. In Mineral Fibres: Crystal Chemistry, Chemical-Physical Properties, Biological Interaction and Toxicity; Gualtieri, A.F., Ed.; European Mineralogical Union: London, UK, 2017; Volume 18, pp. 135-162. 